\title{
Performed Specimen Collection Fasting Status Indicator
}

National Cancer Institute

\section{Source}

National Cancer Institute. Performed Specimen Collection Fasting Status Indicator. NCI

Thesaurus. Code C93961.

Specifies whether the participant had abstained from eating when the specimen is

obtained. 